\title{
MOTIVE AND OBSTACLES IN MAKING A DECISION AS EARLY ADOPTERS OF PSAK NO. 71 FOR IMPAIRMENT PROVISION OF LOANS (STUDY CASE IN INDONESIA BANKING INDUSTRY)
}

\author{
Arya P. Rizal ${ }^{1 *}$ and Elvia R. Shauki ${ }^{2}$ \\ ${ }^{1,2}$ Universitas Indonesia, Indonesia
}

\begin{abstract}
IFRS 9 has converged into PSAK No. 71 and became effective on January 1, 2020 where early implementation is permitted. Changing in accounting standards might have caused controversy. However, there are bank in Indonesia had implemented before PSAK No. 71 effectived (early adopters). This study aims to determine the motive of early adopters of PSAK No.71, the obstacles they faced and the impact especially through loan impairment. By using study case method in Indonesia banking industry and then collect data using semi structured interviews and content analysis. DiMaggio and Powell (1983) explained that institutional theory emphasizes institutional patterns formed because the influence of policy from inside and outside the company (symbolic carriers). Therefore, the motive behind the institutions and actors (material carriers) decision to become early adopters will be revealed. In this case, we found that early adopters are mostly the bank with ownership as foreign bank and mixed bank (as subsidiary). Also, the primary motive of the bank when decide to early adopt are based on following their holding that mandatory to implement IFRS 9. This could create a good external reporting because the accounting standard between holding company and its branch or subsidiary will be similar.
\end{abstract}

Keywords: Banking, Financial Instrument, Early Adopters, Institutional Theory, PSAK No. 71

\section{INTRODUCTION}

Indonesia, as a member of G20 organization, has an obligation to implement International Financial Reporting Standards (IFRS) No. 9 which has been applied effectively on January 1, 2018. In order to adopt the international accounting standard, the Financial Accounting Standards Board of the Indonesian Accountants Association (DSAK-IAI) ratified PSAK No. 71, which is the convergence from IFRS No. 9, on July 26, 2017 and its implementation will be effective on January 1, 2020 and early adoption is allowed. PSAK No. 71 changes the requirements of classification and measurement of financial instruments that previously used PSAK No. 55 which is the convergence from International Accounting Standard (IAS) No. 39.

In order with this, the industry that will be significantly impact is the banking industry. Based on Article 4 (four) Law Act Number 10 in 1998 explained that the purpose of Banking is to support the implementation of national development in order to improve equity, economic growth and national stability towards increasing the welfare of the people. Banking has a function as financial intermediary that aims to collect public funds in a form of deposit and then distribute it in the form of loan. Therefore, banking has a very important role in the economy of a country. Its role showed from Indonesia's financial structure that dominate by the banking industry with total assets $73.69 \%$ or Rp7,354.7 million from the total assets in the financial industry, which is Rp9,980 million in November 2017 (Santoso, 2018).

However, when the bank distribute funds in the form of loan, they were exposed to risk of potential default of this loan. Therefore, bank has to form a provision for impairment loss of loan (CKPN). According to Indonesia Banking Accounting Guidelines (PAPI, 2008) that impairment is an objective evidence of loss after the loan recognized which impact the estimation of the financial asset future cash flows. When

* Corresponding author. Email address : arya.prabu01@gmail.com 
forming a provision for impairment of non performing loan, the bank using debtor data as a basis for analysis. Therefore, the policy and standard operating procedure of each bank will be different with the other. It depends on the size and ownership of the Bank and also the condition of each debtor that they had. However, the policy and standard operating procedure that have been authorized by management must refer to the applicable financial accounting standards so the financial statements will be represent faithfulness (must accurately represent the actual situation). This is important because financial statement was used as a tool by internal and external parties as a stakeholder in order to make a decision.

Enforcement of PSAK No. 71 in Indonesia will certainly make a change to banking accounting practices especially the loan impairment method. Management decision will be influenced by this alteration when making accounting policy and standard operating procedure of the company. PSAK No. 71 will replaced PSAK No. 55 as accounting standard that applied in banking industry today. PSAK No. 71 changes the accounting treatment method of classification and measurement, loan impairment, dan accounting hedge. However, the most significant impact due to this changed is the method in determining the provision for loan impairment. Based on IAI (2016) that PSAK No. 71 was issued with objective to complete the shortcomings of PSAK No. 55. PSAK No. 55 uses the incurred loss method, that is, if there is an evidence that the quality of the value of financial assets decreased means the provision must be formed and on the othe hand, PSAK No. 71 uses the expected loss method, which the provision established if there is a possibility of change in credit risk estimation due to changes in conditions that will decline in the future (IAI, 2016). It is different between PSAK No. 55 that recognizes loss when its occured with the method that use in PSAK No. 71 which recognized the impact of changes in the expected credit loss faster which is after the asset recognized at the beginning. It means the provision that must be formed using PSAK No. 71 will be bigger than using PSAK No. 55. The impact of forming provision for loan impairment will affect the capital and profit of the Bank according to the statement that quoted by the author from the website which is "not only the company's profit and loss that will have a significant impact related to the implementation of PSAK No. 71 but also have a significant impact on capital reduction" (Triana, 2018, http://infobanknews.com/penerapan-psak-71-berdampakpada-penurunan-modal-bank/, accessed 15 May 2018). Therefore, based on the results of the PwC Indonesia survey (2018) that the larger commercial banks (BUKU 3 and 4) are far ahead in their progress in implementing PSAK No. 71 that is $48 \%$ of the total banks were already in the impact assessment stage which is compared to the smaller commercial banks (BUKU 1 and 2) that only 10\% from the total of BUKU 1 and 2. This proved that most of the bank still have not carried out the impact assessment stage due to the complexity of the PSAK.

Furthermore, the adoption of new financial reporting standard caused controversy. This is reflected from the rejection like in France which opposes IFRS to be applied because of the pressure from the political elements that consider the volatility of the balance sheet and also the result of financial statement that produced using this standard will have a negative impact to stakeholders' interests such as decreasing equity (Ball, 2006). Also, there is a complaint that stated there is a violations committed by the rule makers without going through the right process in making IFRS 9 (Bouvier, 2017). Considering IFRS 9 was adopted into PSAK No. 71 then this problem is also suspected to be a problem in Indonesia. However, in practice, there are some commercial bank in Indonesia had implemented PSAK No. 71 earlier before this standard becomes effective even though there is a problem regarding alteration of the accounting standard. Based on the explanation above, the authors conducted a reasearch with title: "Motive and Obstacles in Making a Decision as Early Adopters of PSAK No. 71 for Impairment Provision of Loans (Study Case in Indonesia Banking Industry) ". 


\section{LITERATURE STUDY/HYPOTHESES DEVELOPMENT}

The literature study of this paper discusses the motive and obstacle of the Bank in implementing PSAK No. 71 earlier. In connection with research problems, there are differences between this study and previous studies. The following are the differences:

- Stent (2011) with the title "A Study of Early and Late Adopters of International Financial Reporting Standards in New Zealand". There are differences with previous study that accounting standards are the topic of discussion. In this study examined the implementation of PSAK No. 71 in Indonesia while previous research is the implementation of IFRS in general in New Zealand. Therefore, one of the results of the study from Stent (2011) is that the time taken to choose the early implementation or longer than the new accounting standard is determined by the actor's proactiveness.

- Witjakcono (2017) with the title "ED Impact of PSAK 71 Financial Intrument on Banking Accounting Guidelines Regarding Credit". The purpose of this study was to determine the impact of PSAK No. 71 on Banking Industry and general banking accounting guidelines that issued by regulator. There is a difference between this study and previous research, namely the purpose of the study. Where this paper examines the motivations behind the Bank in making decisions to implement early implementation of PSAK No. 71 especially on credit CKPN and constraints faced while previous paper generally examined the impact of PSAK No. 71 on Banking industry and general banking accounting guidelines (PAPI 2008 and PA-BPR).

Based on the results of previous study and publication journals, it can be concluded that the study of PSAK No. 71 is still limited. Since there is still a gap and need for the research, the author conducted a study to find out the motivations behind the institution and actors inside the Bank when making a decision to choose early implementation of PSAK No. 71 especially towards forming provision of impairment loan and the constraints faced.

\subsection{Statement of Financial Accounting Standards (PSAK) No. 71}

According to Prihadi (2011) that national financial accounting standards are in the process of full convergence with the International Financial Reporting Standard (IFRS) issued by the International Accounting Standards Board (IASB). This must be applied by Indonesia as a member of the countries that incorporated in G20. Following up on any changes to the accounting standard, DSAK-IAI compiled a PSAK that would later be used as a financial accounting standard in preparing financial statements in Indonesia. In Januari 1, 2020, PSAK No. 71 will replaced PSAK No. 55. PSAK No. 71 is a statement of financial accounting standards governing financial instruments which is classification and measurement. This statement is convergenced from IFRS 9 regarding financial instruments: classification and measurement. PSAK No. 71 will replaced PSAK No. 55 (revised 2011) regarding financial instruments: recognition and measurement that adopt IAS 39.

According to IAI (2016), financial instrument is any contract that adds value to financial assets of financial entities and liabilities or equity instruments in other entities. An entity must recognize financial assets or financial liabilities in the statement of financial position when, and only when, the entity becomes part of the contractual provision of the instrument. The most critical impact in this changed will be on financial asset side especially credit or loan. Credit is a word that comes from several languages, namely the Roman language, Credere, which means to believe, the Dutch term Vertrouwen, English, which is believe or trust or confidence which means the same, namely trust (Suparmo, 2009). While the notion of credit according to Law No. 10 of 1998 concerning banking, that credit is the provision of money or equivalent bills, based on agreements or lending and borrowing agreements between the bank and other parties that require the borrowing party to repay its debt after a certain period of time with interest. 
Because of this, a common thread can be drawn that credit is given on the basis of an agreement between the bank and the debtor who has the rights and obligations of each term, interest and sanctions if the agreed upon agreement is denied.

PSAK No. 71 will replaced PSAK No. 55 as accounting standard that applied in banking industry today. PSAK No. 71 changes the accounting treatment method of classification and measurement, loan impairment, dan accounting hedge. First, classification and measurement in PSAK No. 55 divide classification into 4 categories which is Fair Value through Profit / Loss, Available for Sale (AFS), Held to Maturity (HTM) and Loan and Receivables. The classification of each instrument in this standard was determined based on management intention. However, PSAK No. 71 has changed the classification into 3 categories which is Fair Value through Profit / Loss (FVPL), Fair Value through Other Comprehensive Income (FVOCI), and Amortized Cost (AC). The classification of each instrument in this standard was determined not only based on management intention but also using SPPI (Solely Payments of Principal and Interest) test and Business Model test. Second, the accounting treatment method for loan impairments has been changed as well. PSAK No. 71 introduced new approach which is expected credit loss. According to Witjaksono (2017), there is a difference approach in forming provision for impairment of non performing loan between PSAK No. 55 that uses the loss incurred method methodology (there is evidence / information on impairment of financial assets namely historical event and current condition (there is objective evidence) with PSAK No. 71 which uses the expected credit loss methodology (evidence of historical events and current condition but adds also information that is forward-looking. It means the provision that must be formed using PSAK No. 71 will be bigger than using PSAK No. 55. Moreover, the accounting treatment method for Accounting Hedge has been changed as well which is more simplified according to PSAK No. 71 this. In PSAK No. 55 they uses temporary rules while PSAK No. 71 testing effectiveness. However, PSAK No. 71 is more complicated, so the method determined based on qualitative.

As per explanation above, it can be concluded that the most critical impact that affected by the changed in accounting standard will be loan impairment. This is due to forming provision for impairment loan will affect the capital and profit of the Bank. Therefore, in this study, the author will focused on the impact of early implemention of PSAK No. 71 especially on loan impairment.

2.2 Bank

The definition of a Bank according to Law No. 10 of 1998 (Amendment to Law No. 7 of 1992) concerning banking that the definition of a bank is a business entity that collects funds from the public in the form of deposits and distributes them to the public in the form of loans and / or other forms in order to improve people's lives many. Bank are divided based on business activities or called BUKU which adjusted to their core capital. Based on the financial services authority regulation (POJK) number 6 /POJK.03/2016 about business activities and office networks based on bank core capital, bank are divided into 4 categories as follow:

a. BUKU 1 is a bank with core capital less than Rp.1 Billion;

b. BUKU 2 is a bank with core capital of Rp.1 Billion up to less than Rp.5 Billion;

c. BUKU 3 is a bank with core capital of Rp.5 Billion up to less than Rp.30 Billion; and

d. BUKU 4 is a bank with core capital above Rp. 30 Billion.

Currently, there are 115 Bank in Indonesia and based on the data from Indonesian Banking Statistics per December 31, 2017 issued by Financial Service Authority that the distribution of bank according to BUKU can be seen in the table below. 


\begin{tabular}{|l|l|c|}
\hline No & \multicolumn{1}{|c|}{$\begin{array}{c}\text { Group of Bank based on Business } \\
\text { Activities }\end{array}$} & $\begin{array}{l}\text { Total Bank per } \\
\text { BUKU }\end{array}$ \\
\hline 1 & BUKU 1 & 21 Bank \\
\hline 2 & BUKU 2 & 62 Bank \\
\hline 3 & BUKU 3 & 27 Bank \\
\hline 4 & BUKU 4 & 5 Bank \\
\hline & Total All Bank & 115 Bank \\
\hline
\end{tabular}

Sources: Indonesian Banking Statistics per December 31, 2017 issued by OJK

While based on ownership, the type of bank is divided into 5 categories which is state owned bank, national private Bank, union bank, foreign bank, and mixed bank (Thamrin, 2012). In general, the understanding of each ownership according to Thamrin (2012) as follow:

a. State owned bank is a bank whose entire share ownership is owned by the government so all profit the bank received are owned by the government.

b. National private bank is a bank whose entire share ownership is owned by national private parties.

c. Union bank is a bank whose ownership is owned by company with legal entity as union company.

d. Foreign bank is a bank in the form of a branch office where all of its shares are owned by a foreign party.

e. Mixed bank is a bank in the form of subsidiaries whose shares are owned by national private parties and foreign parties.

However, one from five categories of bank ownership above is currently no longer available in Indonesia banking industry which is the bank owned by union company. Furthermore, based on the explanation above, it can be explained that bank have an important role by becoming an intermediary for the public in financial services. In addition, the Bank is grouped based on business activities and ownership.

\subsection{Theoretical Foundation - Institutional Theory}

This theory was introduced by DiMaggio and Powell in 1983 at the first place and over the time has developed further, where institutional theory not only sees the influence of external pressure (isomorphism) but also looks at the behavior of institutions in taking certain policies (institutional logics). This theory basically emphasizes the institutional pattern formed because of the influence of pressure from inside and outside through the process of obedience, imitation and professional demands (DiMaggio and Powell, 1983). According to Lammers and Barbour (2006), institutional theory is described as a series of practices directed based on rational beliefs that are formalized beyond certain organizations and situations. In addition, according to Gidden (in Scott, 2001) that institutions are multidimensional social structures that are built from symbolic elements, social activities, and material resources. One of these theories has a view that plays a very important role in management theory and organization (Greenwood et al., 2008; and Zuckler, 1987) that pressure and dynamics in an environment can form an organization. This theory basically emphasizes the institutional pattern formed because of the influence of pressure from inside and outside through the process of compliance, imitation and professional demands.

According to Hawley (1968), isomorphism is an inhibiting process that enforced a unit in some population to be similar with another units that deal with a similar series of environmental condition. Institutional Isomorphic was changing through three mechanism which is coercive isomorphism (external pressure such as influence from politic), Mimetic isomorphism (by following other institution because of uncertainty) and Normative isomorphism (transformation that result in professionalization) (DiMaggio and Powell, 1983). On the other hand, according 
to Thornton \& Ocasio (2008), institutional logics was design to understand the behaviour of organizational and indvidual which in context of social and institutional so these context can be standardize and giving an opportunity for change and agency. Due to these theories, material carriers in this study are institution or actors that influenced the decision to do early implementation and the symbolic carriers of this study is the standards or rules that the adopter follow which is the requirement of PSAK No. 71 and other relevant regulations, standards or policies. The application of institutional theory in this case study is that the relationship between motivation underlying institutional logics to implement early can be influenced by pressure from inside and outside the company (symbolic carriers) whether it is due to regulatory compliance or shareholder direction, follow other companies or holding, or have become the demands of professionals to become the first company to apply the new accounting standards that applied (or what is referred to as the neo institutional theory). So that it can be seen the motivation of institutions and implementing actors (material carriers) behind the early implementation of PSAK No. 71.

\section{RESEARCH METHODOLOGY}

This study uses a case study method which is a series of scientific activities carried out intensively, in detail and deeply about a program, event, and activity, both at the level of individuals, a group of people, institutions, or organizations to gain indepth knowledge of these events (Raharjo, 2017). The author choose a case study as a study approach because case study can answered the research questions that are the object of this study which is occured of 2 group of commercial bank in Indonesia consist of early adopters and non-adopters of PSAK No. 71. This is related with the function of the case study that analyze in detail a phenomenon so the research question of why a phenomenon happened and how the phenomenon execute in detail can be answered. According to Ellett (2007, p.20), there are several output as a result from study case method which is decision making process, rules determination, evaluation and problem solving.

Furthermore, this study will use the mixed-method approach. According to Shauki (2014), mixed research occurs when researchers and methodologies believe that qualitative perspectives and methods are useful when they discuss their research questions. Usually it will give the most informative, complete, balanced and useful research results. Therefore, it can be concluded that the design of this research method has the objective of completing the deficiencies that exist in quantitative and qualitative research methods and can improve the quality of this case study research. Based on this explanation, the author uses the method in this study to be able to answer the research question.

Moreover, the author used between-method triangulation approach which involving a quantitative approach and a qualitative approach in collecting data. The data that used for this paper are primary data and secondary data. The primary data was obtained from the results of semi structured interviews towards actors at 2 group of commercial bank in Indonesia which is early adopters and non adopters of PSAK No. 71. While for the secondary data, the author use data that has been documented in early adopter Banks which is quarterly financial statements.

The steps that will be carried out in order to collect primary data and secondary data, the author uses sequential exploratory design by collecting data and analyzing qualitative data in the first stage, and followed by collecting quantitative data in the second stage, to strengthen the results of qualitative research conducted the first stage. (Sugiyono, 2011: 409). In the initial stage, the author will examine using qualitative methods, namely semi structured interview. The purpose of this method is to gain a deeper understanding so that the interviews will use the open ended questions that do not limit the answer to questions such as closed questions or multiple choice questions (Shauki, 2018). The interview was conducted to 2 group of commercial bank in 
Indonesia which is early adopters and non adopters PSAK No. 71. The result of semi structured interview will become the source of primary data. At this stage, the author will prepare a list of open ended questions. According to Stake (2005) that the interview steps are as follows:

a. Compile a list of open ended questions that lead to research questions to be used during interviews;

b. Before the list of questions that have been prepared is submitted to the respondent, a trial is conducted on the question;

c. Select appropriate respondent to help answer research questions;

d. Conduct interviews with respondent using questions that have been prepared;

e. Creating guidelines for answering research questions by conducting a qualitative approach to gather information and data from the results of the interview.

After doing the steps above, the non-financial data and information that are qualitative in nature will be grouped through a coding process and then processed it using microsoft office excel applications. Furthermore, the results of research on the qualitative information and data have been obtained, then the author will conduct content analysis of the information that has been obtained from the initial stage and also from the bank's quarterly financial report. This needs to be done to obtain the information that can support data and information from qualitative research that has been carried out in the first stage. While for the unit of analysis for this study are 2 group of commercial bank in Indonesia which is early adopters and non adopters PSAK No. 71. By evaluating the institution or actor in bank motivation in making decisions to early adoption and the obstacles that faced by the Bank.

\section{RESULTS}

The complexity of PSAK No. 71 causes most of the bank in banking industry have not carried out the stages of impact assessment on the implementation of PSAK No. 71 because of the impact in forming provision for impairment loan can affect the capital and profit of the Bank. In addition, changes in accounting standard have caused controversy which is reflected in the rejection of France as opposed to the validity of IFRS because the pressure from the political elements that consider the volatility of the balance sheet and also the result of financial statement that produced using this standard will have a negative impact to stakeholders' interests such as decreasing equity (Ball, 2006). Also, there is a complaint that stated there is a violations committed by the rule makers without going through the right process in making IFRS 9 (Bouvier, 2017). Considering IFRS 9 was adopted as PSAK No. 71 then this problem is suspected to be a problem also in Indonesia. However, in practice there are some commercial bank in Indonesia that have implemented PSAK No. 71 before this standard becomes effective. Therefore, finding will be discussed as per research question which is outlined as follow:

a. How was the motivation and obstacle of a manager in making decisions to implement the PSAK No. 71 early or not from the effective date the accounting standard applies. This research is specifically carried out to answer the following phenomena:

- Are there similarities and differences in decisions made between one bank and another bank?

- Is there a dominant logic behind the manager in making these decisions?

- What institutional factors can trigger / prevent a carrier material from practicing decoupling from existing symbolic carriers?

b. How is the impact of the implementation of PSAK No. 71 by the banking industry especially towards the accounting treatment method for determining the formation of CKPN on non-performing loans? 


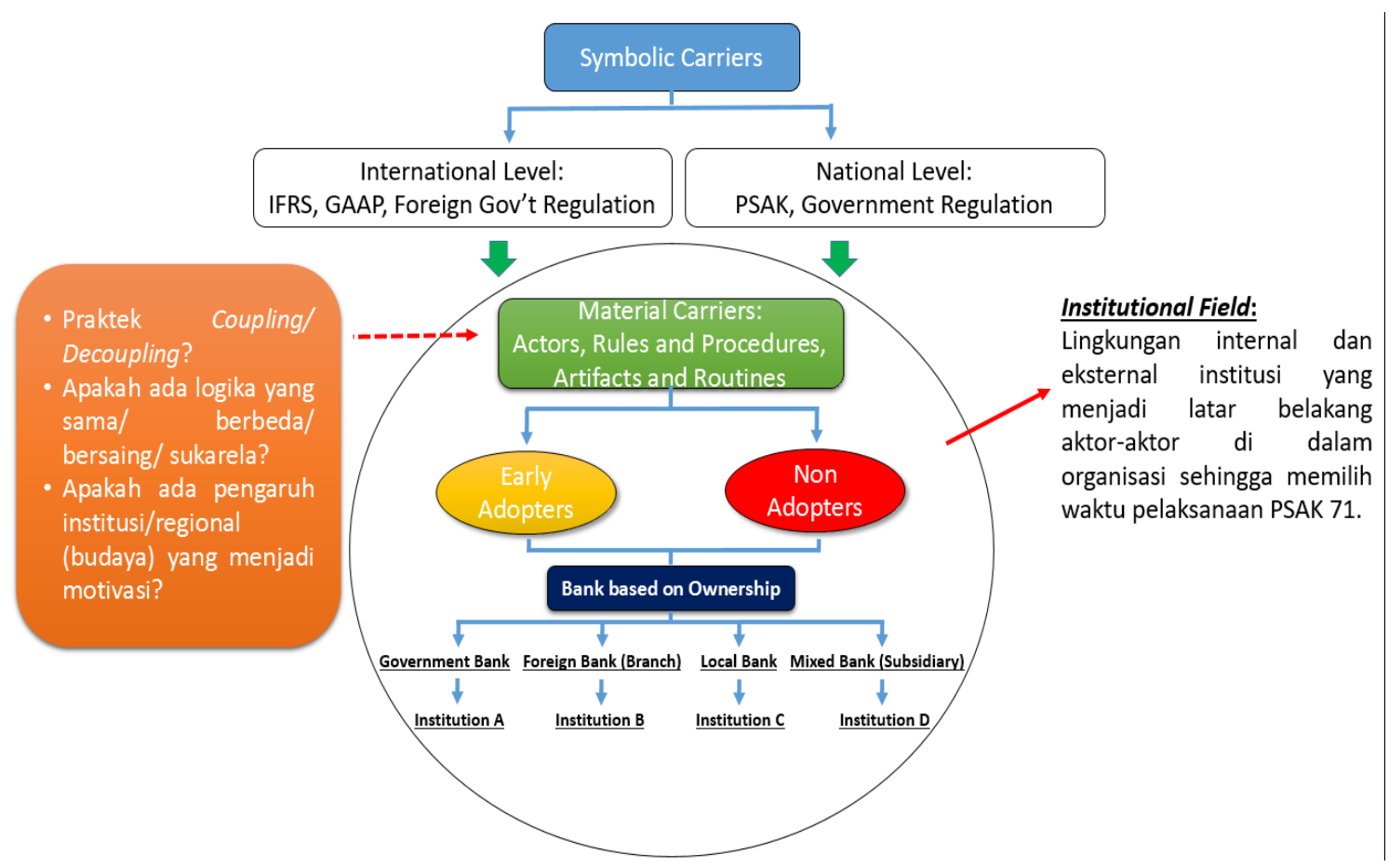

Figure 1. Research Framework Related to Institutional Theory

As per Figure 1 above, the institutional field are group of early adopters and group of non adopters that represent banking industry in Indonesia. The similarity between early adopters group and non adopters group in this paper are based on the ownership of both early adopters group and non adopters group. As for institutional logics, it consists of rule and standard that the adopters follow as symbolic carriers and institution or actor as material carriers that influence Bank in making decision whether to adopt new accounting standard earlier or not.

Furthermore, the author found that the early adopters are mostly the bank with ownership as foreign bank and mixed bank (as subsidiary). Also, the author believes that the motive behind the decision to do early implementation was following their holding company. The holding company of each bank is came from the country that has already effectived implement IFRS 9 that converged into PSAK No. 71 in Indonesia. Therefore, they have an obligation to follow their holding company otherwise there will be a gap due to different accounting standard applied between them. This evidence was found from interview with the actor of the Bank. As a primary motive of the institution or actors inside the Bank when making a decision to early adopt PSAK No. 71 that shown from interview are based on following their holding company that must implement IFRS 9 due to the regulation in their country. Therefore, the accounting standard between their holding company and them will be similar. Also, they can create a good external reporting for stakeholders because the accounting standard that applied in their bank will be similar with their holding company. In addition, the author found that the obstacle when implemented PSAK No. 71 earlier then the effective date was the data is not completed as per required to be use for loan impairment, lack of guidance, and the company infrastructures that can't support the changed. Overall, the impact of implementing this standard will increased number of loan impairment which affect the company equity and also additional cost that arise in implementing PSAK No. 71.

\section{DISCUSSION}

This study aims to determine the motive of early adopters of PSAK No.71 in Indonesia banking industry especially when forming loan impairment provision, knowing the obstacles they faced when applied this standard and also knowing the 
impact of implementing PSAK No. 71 by the banking industry especially in forming provision for loan impairment. By using sample of 2 group of early adopters group and non adopters group of PSAK No. 71 that represent banking industry in Indonesia, the author found that the early adopters are mostly the bank with ownership as foreign bank and mixed bank (as subsidiary).

PSAK No. 71 will replaced PSAK No. 55 as accounting standard that applied in banking industry today. PSAK No. 71 changes the accounting treatment method of classification and measurement, loan impairment, dan accounting hedge. In this case study, the author will limit the scope area only on the impact through loan impairment. The accounting treatment method for loan impairments will changed. PSAK No. 71 introduced new approach which is expected credit loss. According to Witjaksono (2017), there is a difference approach in forming provision for impairment of non performing loan between PSAK No. 55 that uses the loss incurred method methodology (there is evidence / information on impairment of financial assets namely historical event and current condition (there is objective evidence) with PSAK No. 71 which uses the expected credit loss methodology (evidence of historical events and current condition but adds also information that is forward-looking). It means the provision that must be formed using PSAK No. 71 will be bigger than using PSAK No. 55. Therefore, many bank did not want to implement this earlier. However, there are some commercial bank in Indonesia had implemented PSAK No. 71 earlier before this standard becomes effective even though there is a problem regarding alteration of the accounting standard.

The author believes that the primary motive behind the decision to do early implementation was following their holding company. The holding company of each bank is came from the country that mandatory to implement IFRS 9 that converged into PSAK No. 71 in Indonesia. Therefore, they have an obligation to follow their holding company otherwise there will be a gap due to different accounting standard applied between them. This evidence was found from interview with the actor of the Bank. As a primary motive of the institution or actors inside the Bank when making a decision to early adopt PSAK No. 71 that shown from interview are based on following their holding company that must implement IFRS 9 due to the regulation in their country. Therefore, the accounting standard between their holding company and them will be similar. Also, they can create a good external reporting for stakeholders because the accounting standard that applied in their bank will be similar with their holding company.

While the obstacle when implemented PSAK No. 71 earlier then the effective date was the data is not completed as per required to be use for loan impairment, lack of guidance to understand the new standard, and the company infrastructures that can't support the changed. Currently, many Bank didn't want to adopt this standard earlier because of the data is not completed as per required to be use for loan impairment. The data that will use for PSAK No. 71 not only the evidence of historical events and current condition but adds also information that is forward-looking. It means the bank must assess each data of the debtor whether there is an exposure of risk or not. Another obstacle is lack of guidance. PSAK No. 71 is more complex than PSAK No. 55 which is depend on modelling in forming loan impairment. Though they've got training from their holding, while there are still many issues regarding PSAK No. 71 which is still debatable between DSAK IAI, Financial Service Authority and Group of Bank. Therefore, when implementing this standard earlier, the early adopters was using the accounting standard based on IFRS 9 perspective. However, they will found obstacle when it comes to make a judgement due to country matter such as making a modelling using macro economy data in Indonesia or whether forming an impairment or not for product that related to government. Also, the other obstacle is company infrastructures that can't support the changed of accounting standard. This is refer to information technology system, database and the employee which need an improvement because can't support the changed. 
Furthermore, the impact of implementing this standard will increased number of loan impairment which affect the company equity and also additional cost that arise in implementing PSAK No. 71. The number of loan impairment will increased because the method that use in PSAK No. 71 will use forward looking data to determine expected credit lossess, it means the loan that previously not formed impairment will be formed depend on whether there is a credit risk or not. Moreover, additional cost related to cost to improve their human resources, technology information system, hiring a consultant and other infrastructure that related. When we discussed about improvement, there will be cost to spend in earlier adopters while the company has an obligation to achieve certain number of profit as their commitment to shareholder.

The studies about motivation to do early implementation of PSAK No. 71 in Indonesia banking industry had never been done in previous studies. It means this paper will give a contribution for accounting research in Indonesia. Furthermore, if we linked this paper with relevance literaturate, it shows the different result that the motivation to adopt new accounting standard in this paper was based on compliance basis and for previous paper was based actor's proactiveness.

\section{CONCLUSION}

By using sample of early adopters group and non adopters group of PSAK No. 71 that represent banking industry in Indonesia, , the author found that the early adopters are mostly the bank with ownership as foreign bank and mixed bank (as subsidiary). Also, the author aims to determine the motive of early adopters of PSAK No.71 in Indonesia banking industry especially when they formed provision of impairment loan and also knowing the obstacles they face when applied this standard. Therefore, the author found that the institution or actors in the company motive when making a decision whether to choose early implementation or not is based on following their holding company that must implement IFRS 9 due to the regulation in their country so the symbolic carrier between both holding company and its branch or subsidiary company will be similar.

Furthermore, this paper has limitation such as the object of this paper is the company that engaged in banking industry and operating in Indonesia. The result from this paper may show different result if we changed the object into different industry or country because they have different symbolic carriers that need to be followed. The author recommends that further research into industries or countries with different rule from current unit analysis.

\section{References}

Akdon., \& Hadi, S. (2004). Aplikasi Statistik dan Metoda Penelitian Untuk Administrasi dan manajemen. Bandung: Dewi Ruchi.

Apriyani. (2018). Penerapan PSAK 71, Berdampak pada Penurunan Modal Bank, [online], (http://infobanknews.com/penerapan-psak-71-berdampak-padapenurunan-modal-bank/, diakses tanggal 15 Mei 2018).

Ball, R. (2006). International Financial Reporting Standards (IFRS): pros and cons for investors. Accounting and Business Research, International Accounting Policy Forum, 5-27.

Bank Indonesia. (2009). Surat Edaran No. 11/33/ DPNP tanggal 8 Desember 2009 tentang perubahan atas surat edaran No. 11/4/DPNP tanggal 27 Januari 2009 tentang Pelaksanaan Pedoman Akuntansi Perbankan Indonesia.

Bouvier, S. (2017). Accounting standards body rejects complaint over due diligence, [online], 
accounting/accounting-standards-body-rejects-complaint-over-duediligence/10021721.article, diakses tanggal 13 Oktober 2018)

Dewan Standar Akuntansi Keuangan Indonesia. (2016). Exposure Draft Pernyataan Standar Akuntansi Keuangan 71 Instrumen Keuangan, Ikatan Akuntan Indonesia.

Dewan Standar Akuntansi Keuangan Ikatan Akuntan Indonesia, Materi Public Hearing ED PSAK 71 Instrumen Keuangan, Oktober 2016.

DiMaggio, P. J., \& Powell, W. W. (1983). The iron cage revisited: institutional isomorphism and collective rationality in organizational fields. American Sociological Review, 48, 147-160.

Ellet, W. (2007). The Case Study Handbook. Publisher: Harvard Business Press. ISBN 978-1-4221-0158-2.

Doyle, A. (2018). What is a Semi Structured Interview?, [online], (https://www.thebalancecareers.com/what-is-a-semi-structured-interview2061632, diakses tanggal 1 November 2018)

Gatot, S. (2009). Perbankan dan Masalah Kredit: Suatu Tinjauan di Bidang Yuridis. Jakarta: Rineka Cipta

Hasibuan, H. Malayu SP, 2011. Dasar-dasar perbankan. Jakarta: PT.Bumi Aksara

Ikatan Akuntan Indonesia (IAI). (2016). Standar Akuntansi Keuangan revisi. 2016. Salemba Empat. Jakarta.

Ismail. (2010). Manajemen Perbankan dari Teori Menuju Aplkasi. Penerbit Kencana. Jakarta.

Kasmir. (2012). Dasar-Dasar Perbankan, Edisi Revisi. PT. Raja Grafindo Persada.

Johnson, R.B. \& Onwuegbuzie, A.J. (2004). Mixed Methods Research: A Research Paradigm Whose Time Has Come. Educational Researcher, 33, 14-26. http://dx.doi.org/10.3102/0013189X033007014

Martani, D. (2018). Belajar ED PSAK 71 Instrumen Keuangan. https://staff.blog.ui.ac.id/martani/2016/11/18/belajar-ed-psak-71-instrumenkeuangan, (diakses pada tanggal 10 Maret 2018).

Muhammad. T. (1999). Perkreditan Bisnis Inti Perbankan. Jakarta: PT. Gramedia Pustaka Utama.

Prihadi, T. (2011). Laporan Keuangan Sesuai IFRS \& PSAK. PPM Manajemen. Jakarta.

PWC Indonesia. (2017). Indonesia Banking Survey 2017. Jakarta

Rahardjo, M. (2017). Studi Kasus dalam penelitian Kualitatif: Konsep dan Prosedurnya. Malang: Universitas Islam Negeri Maulana Malik Ibrahim.

Republik Indonesia, Undang-Undang Nomor 7 Tahun 1992 tentang Perbankan sebagaimana telah diubah dengan Undang-undang Nomor 10 Tahun 1998, 
AFEBI Accounting Review (AAR)

Vol.03 No.02, December 2018

Lembaran Negara Republik Indonesia Tahun 1998 Nomor 182, Tambahan Lembaran Negara Republik Indonesia Nomor 3790.

Santoso, W. (2018). Fostering Growth. Annual Financial Executive Gathering. Tanggal 18 Januari 2018. Jakarta, Indonesia.

Scott, W. R. (2001). Institutions and organizations. Thousand Oaks, CA: SAGE.

Scott, W.R. (2004). Encyclopedia of Social Theory. Thousand Oaks, CA: Sage

Shauki, E.R.,"Qualitative and Mixed-Method Research Analysis Using Nvivo 11", Handout, Case Writing and Methodology, ECAM 809303, (Elvia R. Shauki, $\mathrm{PhD}$ ) University of Indonesia, April 2018. Print.

Stake, R. E. (2005). Qualitative Case Studies. In N. K. Denzin \& Y. S. Lincoln (Eds.), The Sage handbook of qualitative research (pp. 443-466). Thousand Oaks, CA,: Sage Publications Ltd.

Sugiyono. (2011). Metode Penelitian Kuantitatif, Kualitatif dan R\&D. Bandung: Afabeta.

Witjakcono A. (2017). Dampak ED PSAK 71 Intrumen Keuangan Terhadap Pedoman Akuntansi Perbankan Terkait Kredit. Jurnal Online Insan Akuntan. 2 (1): 35 48.

Yasril., \& Kasjono, H. S. (2009). Analisis Multivariat Untuk Penelitian Kesehatan. Penerbit Mitra Cendikia. Yogyakarta.

Zuckler, G.L. (1987) Institutional Theories of Organization. Annual Review of Sociology, Vol.13, pp. 443-464 